\title{
Job Satisfaction of Anganwadi Teacher's: A Study
}

\author{
Dr. S. Vijayavardhini ${ }^{1 *}$, Mrs. T. Aruna Kumari ${ }^{2}$
}

Keywords: Job satisfaction, Anganvadi Teacher, Life, Health.

Early childhood is one of the most crucial and formative period in the life of any individual. Many psychologists believed that the first six years in the life of an individual is very significant period in the developmental stages especially its lays foundation for healthy and wholesome development of the personality. The research studies proved that pre-school education plays a crucial role in the development of young children before they enter into formal schooling. The pre-school education prepares the child for tomorrow and also helps in his/her cognitive development. Pre-school education is considered to be very significant for the child as it is the first step towards enterning into the world of knowledge as well as a healthy person. It aims at satisfying the Childs physical, mental, emotional and social needs. Pre-school education helps in laying down a healthy foundation for the all round development of the child. It allows the children to expose their inner skills and talents, so that the children develop their personality. It also provides opportunity to the children to give vent to their inner desires in a positive way.

Pre-school education teaches not only social skills to the children and also develops their ability to adjust in its school environment and also teach them how to deal with bullies. Good Preprimary schools ensure the children to attend the school happily instead of avoiding and hesitant to go to school due to bullies. Pre-school attract the children by providing toys, showing pictures and by using play way method of instruction and also giving lot of freedom to them. PreSchooling encourages group activities, at the same time they teach the importance of discipline. A child to grow into a healthy, socially well adjusted individual, pre-school education is essential.

\section{Need of the study:}

Teacher plays a pivot role in system of education as the saying goes 'Teachers are the real Architects a Nation'. The greatness of any country does not depends on huge buildings, gigantic projects and on large armies, but it is on the quality of her citizens. It is the teacher who plays a vital role in shaping the future citizens of a country by paying much attention on the young

\footnotetext{
${ }^{1}$ Assistant Professor, Dravidian University, Kuppam

${ }^{2}$ Research Scholar, Dept. of Education \& HRD

*Responding Author

(C) 2016 I S Vijayavardhini, A Kumari; licensee IJIP. This is an Open Access Research distributed under the terms of the Creative Commons Attribution License (http://creativecommons.org/licenses/by/2.0), which permits unrestricted use, distribution, and reproduction in any Medium, provided the original work is properly cited.
} 
children who were entrusted to their care. The teacher is one who not only a interpreter of culture and dispenser of knowledge but also builds right attitudes, Inculcate values and beliefs. By noticing the importance of teacher, various commissions and committees made several recommendations on teacher training from pre-school education to Higher Secondary Education.

In this context teacher's job satisfaction is very much essential. In the field of education job satisfaction is a crucial factor in promoting quality education. If the teachers are not happy in their profession they may not disseminate proper knowledge, required skills to the students. In view of Hippck Job Satisfaction is any combination is of psychological, physiological and environmental circumstances that cause a person to faithfully say "I am satisfied with my Job". So it is very clear that any person in any job must be satisfied with their work. The satisfaction in job will give better results in any organization. When we talk about education system, Teacher's play enamors role so that they should be satisfied in their job. Job Satisfaction of a person is related to so many other areas like Job environment, Nature of job, co-workers, salary, students so on and so forth, with all these dimensions a teachers Job Satisfaction is linked. As we discussed earlier Pre-Primary education is the bed rock for the future of the child. A teacher who teaches in Pre-Primary school i.e. Anganwadi School, who is called as Anganwadi teacher or Anganwadi worker also need Job Satisfaction. Through various reach studies it is came to know that may teachers from pre-school to university level that they are not satisfied with their job. Therefore the researcher made an attempt to find out the job satisfaction of Anganwadi teachers in Kuppam and Gudipalli mandals. These two mandals are named as backward mandals in Chittoor District. Most of the people living in these mandals are illiterates and working in fields as daily labourers and many are moving to nearby city to earn their livelihood. Parents leave their children at home or in anganwadi centres and go to their work places. The Anganwadi teachers are taking care of the many young children as and playing a vital role in looking after and providing balanced food given by the government for them. Hence at this juncture the researcher felt it in the need of the hour to find out the job satisfaction of Anganwadi teacher working in Kuppam and Gudipalli mandal of Chittoor District.

\section{OBJECTIVES:}

1. To assess the level of Job Satisfaction of Anganwadi teachers.

2. To find out significant difference if any in the Job Satisfaction of Anganwadi teachers with respect to their Age, Educational qualifications and Experience.

\section{Hypotheses:}

- There is no significant difference in the Job Satisfaction of Anganwadi Teachers due to variation in their
i) Age.
ii) Educational qualification.
iii) Experience. 


\section{METHODOLOGY}

By noticing the purpose and scope of the study, the researcher adopted normative survey method.

\section{Local and Sample of the Study:}

To study the present problem the researcher selected Kuppam and Gudipalli mandals in Chittoor District of Andhra Pradesh. There are 84 Anganwadi centers in the two mandals. For the purpose of the study the investigator selected 50 Anganwadi centers by using "Simple Random Sample Technique" the teachers who are working in the 50 selected mandals were considered as sample of the study. Thus the total sample of the study is 50 Anganwadi teachers.

\section{Tool:}

After thorough review of research studies conducted by Amarnath Babu, (2003), Rao, (2005), Kumar and Mathu, (2008), Reddy, (2007 and 2010) on Job Satisfaction, the researchers developed her own tool and establish validity and reliability of the tool. The tool consisted of five dimensions, i.e. i) Satisfaction with organization, ii) Satisfaction with the profession, iii) Satisfaction with self, iv) Satisfaction with Stake holder, v) Satisfaction with the Supervisors and co-workers.

\section{Data Analysis:}

Depending upon the nature of the study appropriate statistical techniques were employed like percentages, \pm 1 SD, Mean, SD, t-test and 'F' ratio.

\section{RESULTS AND DISCUSSIONS}

\section{Job Satisfaction of Anganwadi Teachers}

One of the major objectives of the study is to assess the job satisfaction levels of Anganwadi Teachers working in Kuppam and Gudipalli mandals. For this, the investigator has taken up item wise analysis. Mean and SD for each item has been calculated. Based on mean \pm 1 SD, the job Satisfaction statements has been divided into three groups, i.e. low, moderate and high levels. The same is presented in table-I and interpreted accordingly.

Table-1: Mean Job Satisfaction Scores and the Levels of Job Satisfaction of Anganwadi Teachers

\begin{tabular}{|l|l|l|l|}
\hline $\begin{array}{l}\text { S. } \\
\text { No. }\end{array}$ & Job Satisfaction of Anganwadi Teachers & $\begin{array}{l}\text { Mean } \\
\text { Score }\end{array}$ & $\begin{array}{l}\text { Level of Job } \\
\text { Satisfaction }\end{array}$ \\
\hline \multicolumn{2}{|l|}{ I. Satisfaction with the Organisation } \\
\hline $1 . \quad \begin{array}{l}\text { I am happy with the favorable environment for } \\
\text { working in my Anganwadi centre }\end{array}$ & 4.6 & $\mathrm{M}$ \\
\hline $\begin{array}{l}\text { It gives me pleasure in performing multiple roles in } \\
\text { Anganwadi Centre }\end{array}$ & 4.98 & $\mathrm{M}$ \\
\hline
\end{tabular}




\begin{tabular}{|c|c|c|c|}
\hline 3. & $\begin{array}{l}\text { Due to work stress I am unable to fulfill my work } \\
\text { properly }\end{array}$ & 4.1 & M \\
\hline 4. & $\begin{array}{l}\text { It gives me pleasure while teaching as the centre got } \\
\text { adequate teaching learning material, for example } \\
\text { toys which facilitate to work comfortably }\end{array}$ & 4.6 & M \\
\hline 5. & Our Anganwadi centre has its own building. & 2.88 & $\mathrm{~L}$ \\
\hline 6. & $\begin{array}{l}\text { I feel difficult in my Anganwadi centre due to more } \\
\text { student strength }\end{array}$ & 3.6 & $\mathrm{~L}$ \\
\hline 7. & $\begin{array}{l}\text { I feel it difficult to participate in each and every } \\
\text { activity in the Anganwadi centre }\end{array}$ & 3.6 & $\mathrm{~L}$ \\
\hline \multicolumn{4}{|c|}{ II. Satisfaction with the Profession } \\
\hline 9. & $\begin{array}{l}\text { Compare to other professions, Teaching is a } \\
\text { dignified profession }\end{array}$ & 4.92 & M \\
\hline 10. & $\begin{array}{l}\text { I forget my sorrows and problems while I am } \\
\text { working with children }\end{array}$ & 4.9 & $\mathrm{M}$ \\
\hline 11. & I have self satisfaction in my profession & 4.7 & $\mathrm{M}$ \\
\hline 12. & I am not happy satisfied with my profession & 3.66 & $\mathrm{~L}$ \\
\hline 13. & My works demands more, but paid only less salary & 3.44 & $\mathrm{~L}$ \\
\hline 14. & I am doing my work with sincerity and commitment & 4.9 & $\mathrm{M}$ \\
\hline \multicolumn{4}{|c|}{ III. Satisfaction with the Self } \\
\hline 15. & Teaching Profession gives me self Satisfaction & 4.98 & $\mathrm{M}$ \\
\hline 16. & Teaching in Anganwadi Centre is peaceful & 4.88 & M \\
\hline 17. & I decided to continue in this profession & 4.94 & M \\
\hline 18. & $\begin{array}{l}\text { As I am providing good nutrition food to the } \\
\text { children's as per government rules I am satisfied }\end{array}$ & 4.96 & M \\
\hline 19. & $\begin{array}{l}\text { I am happy that the pregnant women the village are } \\
\text { benefited out of my job }\end{array}$ & 4.96 & M \\
\hline \multicolumn{4}{|c|}{ IV. Satisfaction with the stake-holders } \\
\hline 20. & $\begin{array}{l}\text { It is difficult to deal with parents while conducting } \\
\text { meeting in the Anganwadi Centre }\end{array}$ & 4.68 & M \\
\hline 21. & $\begin{array}{l}\text { I feel so difficult in my Anganwadi centre because } \\
\text { we don't have drinking water and toilet facilities. }\end{array}$ & 2.6 & $\mathrm{~L}$ \\
\hline 22. & $\begin{array}{l}\text { I have sufficient time for recreation and looking after } \\
\text { the welfare of my family. }\end{array}$ & 4.96 & M \\
\hline 23. & I enjoy my work more than my leisure & 4.98 & $\mathrm{M}$ \\
\hline 24. & $\begin{array}{l}\text { Aya in the Anganwadi centre is not regular which is } \\
\text { disturbing me to perform my job. }\end{array}$ & 3.32 & $\mathrm{~L}$ \\
\hline 25. & I am getting a salary commensurate with my work. & 3.02 & $\mathrm{~L}$ \\
\hline 26. & There are opportunities for promotion in my Job. & 3.30 & $\mathrm{~L}$ \\
\hline 27. & My friends and relatives pay due regard to my profession & 4.94 & $\mathrm{M}$ \\
\hline
\end{tabular}




\begin{tabular}{|c|c|c|c|}
\hline \multicolumn{4}{|c|}{ V. Satisfaction with the Supervisors and Co-workers } \\
\hline 28. & $\begin{array}{l}\text { My supervisors are providing adequate supportive } \\
\text { system. }\end{array}$ & 4.96 & M \\
\hline 29. & $\begin{array}{l}\text { My colleges extend supportive system whenever } \\
\text { needed. }\end{array}$ & 4.26 & M \\
\hline 30. & $\begin{array}{l}\text { I am able to develop rapport with my colleges and } \\
\text { happily adjusted. }\end{array}$ & 4.82 & M \\
\hline 31. & There is freedom for me to plan my work & 4.8 & $\mathrm{M}$ \\
\hline 32. & $\begin{array}{l}\text { Good relationship exists between teacher and } \\
\text { students in my Anganwadi centre. }\end{array}$ & 4.74 & M \\
\hline 33. & There is security of Job as long as I do good work. & 4.9 & $\mathrm{M}$ \\
\hline 34. & $\begin{array}{l}\text { I receive appreciation for my good work from my } \\
\text { superiors }\end{array}$ & 4.52 & M \\
\hline 35. & $\begin{array}{l}\text { My fellow workers are always ready to render their } \\
\text { help when I need it }\end{array}$ & 4.92 & M \\
\hline 36. & I feel a sense of dignity in the job & 5 & $\mathrm{M}$ \\
\hline
\end{tabular}

Note: Level of Job satisfaction

1. Low level -3.6 and below

2. Moderate level - 3.6 to 5.1

3. High level -5.2 and above

Table - I shows that in first dimension the Anganwadi Teachers possess low level of job satisfaction in S.No. 6,7 and 9, moderate level of job satisfaction in S. No. 1,2,3 and 5.

In the dimension 'satisfaction with the Profession, the Anganwadi Teachers possess low level of job satisfaction in S.No.13, 14 moderate level of job satisfaction in S.No. 10, 11, 12, 15.

In the third dimension i.e., 'satisfaction with the self the Anganwadi teachers possess moderate level of job satisfaction in all statements [S.No. 16, 17, 18, 19 and 20].

In case of 'satisfaction with the stake-holders', the Anganwadi Teachers possess low level of job satisfaction in S.No.22, 24 and moderate level of job satisfaction in S.No.21, 23, 25, 26 and 27.

In 'satisfaction with supervisions \& co-workers' the Anganwadi Teachers possess moderate level, of job satisfaction in all statements (S.No. 28, 29, 30,31, 32, 33, 34 and 35).

As a whole, out of 35 statements Anganwadi Teachers possess low level of job satisfaction in 8 statements, while the Anganwadi Teachers possess moderate level of job satisfaction in 27 statements. 
Table - 2: Mean and SD, of the Job Satisfaction Scores of Anganwadi Teachers with different Age groups and the calculated t-values

\begin{tabular}{|c|c|c|c|c|c|c|}
\hline \multirow{3}{*}{$\begin{array}{l}\text { S. } \\
\text { No. }\end{array}$} & \multirow{3}{*}{ Job Satisfaction Dimensions } & \multicolumn{4}{|c|}{ Age Group } & \multirow{3}{*}{$\begin{array}{l}\text { Calculated } \\
\text { value }\end{array}$} \\
\hline & & \multicolumn{2}{|c|}{$\begin{array}{l}\text { Below } 30 \text { yrs } \\
(\mathrm{N}=23)\end{array}$} & \multicolumn{2}{|c|}{$\begin{array}{l}31 \text { yrs and } \\
\text { above }(N=27)\end{array}$} & \\
\hline & & Mean & SD & Mean & SD & \\
\hline 1 & $\begin{array}{l}\text { Satisfaction with the } \\
\text { Organization }\end{array}$ & 36.9 & 4.7 & 35.7 & 5.2 & @0.2 \\
\hline 2 & $\begin{array}{l}\text { Satisfaction with the } \\
\text { Profession }\end{array}$ & 26.4 & 2.97 & 25.1 & 3.4 & @0.37 \\
\hline 3 & Satisfaction with the Self & 19.8 & 0.81 & 19.7 & 1.0 & @0.5 \\
\hline 4 & $\begin{array}{l}\text { Satisfaction with the Stake } \\
\text { Holders }\end{array}$ & 34.4 & 3.2 & 34.5 & 3.3 & @0.1 \\
\hline 5 & $\begin{array}{l}\text { Satisfaction with the } \\
\text { Supervisors \& Co-workers }\end{array}$ & 37.1 & 3.2 & 38.7 & 1.75 & $* 2.4$ \\
\hline 6 & Job Satisfaction as a whole & 154.6 & 14.8 & 154.7 & 14.6 & @0.01 \\
\hline
\end{tabular}

Table-2 shows that the obtained ' $t$ ' value with respect to the dimensions satisfaction with the organization (0.2), satisfaction with the Job (0.37), satisfaction with the stake holders (0.1) and satisfaction with the satisfaction with the self $(0.5)$ are not significant at 0.05 level. It can be that the Anganwadi Teachers belonging to below 30 years and 31 years and above years of age group are not significantly differ in their job satisfaction.

Hence, the formulated hypothesis, 'there is no significant difference in the job satisfaction of Anganwadi teachers due to variation in their Age' is accepted with respect to the dimensions of satisfaction with the organization, satisfaction with the Profession, satisfaction with the self, satisfaction with the stake holders and job satisfaction as a whole and the same hypothesis is rejected with respect to the dimension satisfaction with the supervisors and co-workers (2.4) and significant at 0.05 level. It can be said that the Anganwadi Teachers belonging to below 30 years and 31 years and above age group significantly differ in their job satisfaction. Further the mean values revels, that the teachers belonging to 31 years and above age group enjoy high level of job satisfaction when compared to the Anganwadi teachers belonging to below 30 years of age group. 
Table - 3: Mean and SD, of the Job Satisfaction Scores of Anganwadi Teachers and the calculated't'-values based on their Educational Background

\begin{tabular}{|c|c|c|c|c|c|c|}
\hline \multirow{3}{*}{$\begin{array}{l}\text { S. } \\
\text { No. }\end{array}$} & \multirow{3}{*}{ Job Satisfaction Dimensions } & \multicolumn{4}{|c|}{ Educational Qualification } & \multirow{3}{*}{$\begin{array}{l}\text { Calculated ' } t \text { ' } \\
\text { value }\end{array}$} \\
\hline & & \multicolumn{2}{|c|}{$\mathrm{X}$ Class $(\mathrm{N}=36)$} & \multicolumn{2}{|c|}{$\begin{array}{l}\text { Intermediate } \quad \text { and } \\
\text { above }(N=14)\end{array}$} & \\
\hline & & Mean & SD & Mean & SD & \\
\hline 1 & $\begin{array}{lll}\text { Satisfaction } & \text { with } & \text { the } \\
\text { Organization } & & \end{array}$ & 36.4 & 4 & 26.7 & 3.02 & $* 8.6$ \\
\hline 2 & Satisfaction with the Profession & 27.08 & 3.7 & 26.7 & 3.02 & @0.1 \\
\hline 3 & Satisfaction with the Self & 19.86 & 0.82 & 19.5 & 1.2 & @1.38 \\
\hline 4 & $\begin{array}{l}\text { Satisfaction with the Stake } \\
\text { Holders }\end{array}$ & 32.6 & 4.4 & 36.2 & 3.05 & @0.3 \\
\hline 5 & $\begin{array}{l}\text { Satisfaction with the } \\
\text { Supervisors \& Co-workers }\end{array}$ & 38.86 & 3.7 & 39.5 & 1.11 & @0.09 \\
\hline 6 & Job Satisfaction as a whole & 154.8 & 16.6 & 148.6 & 11.4 & @0.3 \\
\hline
\end{tabular}

Table-3, shows that the obtained t-values with respect to the dimensions satisfaction with the Profession (0.1), satisfaction with the self (1.38), and satisfaction with the stake holders (0.3) Satisfaction with the supervisors and co-workers (0.09) are not significant at 0.05 level. Hence, it can be said that the Anganwadi Teachers with $\mathrm{X}$ class, intermediate and above educational qualifications has not significantly differed in their job satisfaction.

Hence, the formulated hypothesis there is no significant difference in their job satisfaction of Anganwadi teachers due to variation in their educational qualifications' is accepted. Where as with respect to the satisfaction with the organization, the calculated't' value (8.6) which is significant at 0.05 level. Hence, the formulated hypothesis with respect to the dimension satisfaction with the organization is rejected.

It can be conduced that the Anganwadi Teachers with X class, intermediate and above education qualifications significantly differ in their job satisfaction. As a whole it can be said that the variable "Educational Qualifications” of Anganwadi Teachers has significantly influenced their job satisfaction. Further the mean values reveals that the teachers with X Class group enjoy high level of job satisfaction than the Anganwadi Teachers belonging Intermediate and above qualification. In other words, it is higher the educational qualification, higher will be the job satisfaction. 
Table -5: Showing sum of Squares, Mean Squares of Anganwadi Teachers with varied Years of Experience and the calculated F-values

\begin{tabular}{|c|c|c|c|c|c|c|}
\hline $\begin{array}{l}\text { S. } \\
\text { No. }\end{array}$ & $\begin{array}{l}\text { Job Satisfaction of } \\
\text { Anganwadi } \\
\text { Dimensions }\end{array}$ & $\begin{array}{l}\text { Source of } \\
\text { variation }\end{array}$ & $\begin{array}{l}\text { Sum of } \\
\text { Squares }\end{array}$ & df & $\begin{array}{l}\text { Mean } \\
\text { square }\end{array}$ & F ratio \\
\hline \multirow{2}{*}{1.} & \multirow{2}{*}{$\begin{array}{l}\text { Satisfaction with the } \\
\text { Organization }\end{array}$} & $\begin{array}{l}\text { Between } \\
\text { groups }\end{array}$ & 97.6 & 2 & 48.8 & \multirow{2}{*}{ @1.2 } \\
\hline & & $\begin{array}{l}\text { Within } \\
\text { groups }\end{array}$ & 77.5 & 47 & 1.64 & \\
\hline \multirow{2}{*}{2.} & \multirow{2}{*}{$\begin{array}{l}\text { Satisfaction with the } \\
\text { Profession }\end{array}$} & $\begin{array}{l}\text { Between } \\
\text { groups }\end{array}$ & 58.3 & 2 & 29.1 & \multirow{2}{*}{ @0.3 } \\
\hline & & $\begin{array}{l}\text { Within } \\
\text { groups }\end{array}$ & 18.7 & 47 & 3.8 & \\
\hline \multirow{2}{*}{3.} & \multirow{2}{*}{ Satisfaction with the Self } & $\begin{array}{l}\text { Between } \\
\text { groups }\end{array}$ & 146.4 & 2 & 73.2 & \multirow{2}{*}{ @0.2 } \\
\hline & & $\begin{array}{l}\text { Within } \\
\text { groups }\end{array}$ & 5.13 & 47 & 10.9 & \\
\hline \multirow{2}{*}{4.} & \multirow{2}{*}{$\begin{array}{l}\text { Satisfaction with the Stake } \\
\text { Holders }\end{array}$} & $\begin{array}{l}\text { Between } \\
\text { groups }\end{array}$ & 80.6 & 2 & 40.3 & \multirow{2}{*}{ @0.7 } \\
\hline & & $\begin{array}{l}\text { Within } \\
\text { groups }\end{array}$ & 115 & 47 & 2.4 & \\
\hline \multirow{2}{*}{5.} & \multirow{2}{*}{$\begin{array}{l}\text { Satisfaction with the } \\
\text { Supervisors } \\
\text { Co-workers }\end{array}$} & $\begin{array}{l}\text { Between } \\
\text { groups }\end{array}$ & 98.3 & 2 & 49.1 & \multirow{2}{*}{ @0.15 } \\
\hline & & $\begin{array}{l}\text { Within } \\
\text { groups }\end{array}$ & 617.7 & 47 & 13.1 & \\
\hline
\end{tabular}

Table- 5 shows that the obtained F-values with respect to the dimensions satisfaction with the organization (1.2), satisfaction with the Profesion (0.3), satisfaction with the self (0.2), satisfaction with the stake holders (0.7), satisfaction with the supervisors \& co-workers (0.15) are not significant at 0.05 levels. Therefore, it can be said. That the Anganwadi Teachers with 5years and below, 6-10 years and, 11 years and above years of experience has not significantly influenced their job satisfaction. Hence, the formulated hypotheses 'there is no significant difference in their job satisfaction of Anganwadi teachers due to variation in their years of experience is accepted.

From the above, it is concluded that the variable 'years of experience' of Anganwadi Teachers has not significantly influenced of their job satisfaction. 


\section{FINDINGS}

1. The results reveal that out of 35 statements, Anganwadi Teachers possess low level of job satisfaction statements, in 8 statements and moderate level of job satisfaction in 27 statements. They haven't reveled high level of job satisfaction in any one statement.

2. The variable 'age' of Anganwadi teachers has not significantly influenced their job satisfaction.

3. The variable 'Educational qualifications' of Anganwadi teachers has significantly influenced their job satisfaction.

4. The variable 'Years of Experience' of Anganwadi Teachers has not significantly influenced their job satisfaction.

5. The null hypothesis stating that "There is no significant influence of age of Angawandi Teachers on the different dimensions towards job satisfaction" was accepted in all dimensions but rejected in case of satisfaction with the supervisors and co-workers.

6. The null hypothesis stating that "There is no significant influence of Education qualification of Angawandi Teachers on the different dimensions towards job satisfaction" was accepted in all dimensions but rejected in case of satisfaction with the organization.

7. The null hypothesis stating that "There is no significant influence of Years of Experience of Angawandi Teachers on the different dimensions towards job satisfaction” was accepted in all dimensions.

\section{IMPLICATIONS OF THE STUDY}

The study reveals that in most of the aspects the teachers possess only moderate level of job satisfaction. It is clear that there is a need for development of healthy relationships among workers apart from developing good communication channels between the supervisors and coworkers. It is also clear that in order to reduce their work load, one more Anganwadi Teacher should be appointed to share the roles. The student's teacher ratio should be reduced to Anganwadi Centre. The rules and regulations should be spelt out clearly in written by not giving any scope to ambiguity. Rules should be applied uniformly to all the Anganwadi Teachers without any favoritism to instill confidence in teachers on the management.

The infrastructure facilities should be developed in terms of adequate space for the teachers to sit and work, providing better work environment, safe drinking water facilities, adequate health care amenities within the school. Further, the salary structure is low to Anganwadi Teachers when compared to other teachers. It has to be enhanced on par with the other teachers which improves their job security.

Also, the Anganwadi Teachers possessing intermediate qualification enjoy high level of job satisfaction which suggests that Anganwadi Teachers should further given opportunity to possess higher education related to their profession in order to have high job satisfaction which in turn leads for good job performance. 
According to the many research studies the Anganwadi Teachers working in semi-urban Anganwadi centers possess high level of job satisfaction. Compare to rural areas. This gives scope to improve the Anganwadi centers located in rural areas on with the semi-urban Anganwadi centers.

\section{CONCLUSION:}

The study revealed that the Anganwadi teachers possessed moderate level of Job Satisfaction in the dimensions related to i) supervisors and co-workers, ii) stake holders, they possessed low level of Job Satisfaction with respect to organization and infrastructure facilities. Therefore, it is evident that there is a need of development of healthy relationships with supervisors and coworkers. There is a need of increasing the number of teachers according to the student strength, so that children can be given individual attention. Even the minimum qualifications of Anganwadi teachers should be changed from $10^{\text {th }}$ class to intermediate along with pre-school teacher training. Therefore the teachers can understand the children's problem and also help for their all round development.

The infrastructure facilities should be adequate and maintained properly. Health care amenities must be provided for the children. School environment should be free from all barriers. The Salary component must be raised, on par with other teachers so that the Anganwadi teachers will get job security which inturn enhance their Job Satisfaction.

\section{REFERENCES}

Janardan Prasad (2005) “Education and the Teacher” Kanishika Publishers Distributions 4697/521A Ansari Road, Darya Ganj, New Delhi-110002.

Mohit Chakrabarti (2012) “Teacher Education Modern Trends” Kanishika Publishers Distributions 4697/5-21A, Ansari Road Darya Ganj, New Delhi-110002.

Pramila Sharma (2010) “Teacher Education” S.B. Nangia A.P.H Publishing Corporation 443536/7, Ansari Road., Darya Ganj, New Delhi-110002.

Prof. S.C. Panigrahi, Dr. Ashutosh Biswal (2012) “Teacher Education” A.P.H. Publishing Corporation 4435-36/7, Ansari Road, Darya Ganj, New Delhi-110002.

Ranjit Kumar (2011) “Research Methodology” SAGE Publications India Pvt., Ltd., B1/1-1 Mohn Cooperative Industrial Area, Mathura Road, New Delhi-110044.

S.K. Panneer Selvam (2011) “Teacher Education” A.P.H. Publishing Corporation 4435-36/7, Ansari Road, Darya Ganj, New Delhi-110002.

Vijayakumari Kanshik and S.R. Sharma (2002) “Teaching Methods for Secondary Education” Anmol Publications Pvt., Ltd., 4374/4B Ansari Road Darya Gang, New Delhi-110002. 